九州大学学術情報リポジトリ

Kyushu University Institutional Repository

\title{
Occurrence of Obolodiplosis robiniae (Diptera: Cecidomyiidae) in Japan and South Korea
}

Kodoi, Fumio

Lee, Heung-Sik

Uechi, Nami

Yukawa, Jun-ichi

https://doi.org/10.5109/2671

出版情報: ESAKIA. 43，pp.35-41，2003-03-31. Entomological Laboratory，Faculty of Agriculture， Kyushu University

バージョン :

権利関係 : 
Esakia, (43): 35 - 41. March 31, 2003

\title{
Occurrence of Obolodiplosis robiniae (Diptera: Cecidomyiidae) in Japan and South Korea*
}

\author{
Fumio KODOI \\ Entomological Laboratory, Graduate School of Bioresource and Bioenvironmental Sciences, \\ Kyushu University, Fukuoka, 812-8581 Japan
}

Heung-Sik $\mathrm{LEE}$

Laboratory of Insect Systematics, College of Agriculture and Life Science, Seoul National University, Seodundong, 103 Kwonseongu, Suwon, 441-744 South Korea

\section{Nami UECHI}

Entomological Laboratory, Graduate School of Bioresource and Bioenvironmental Sciences, Kyushu University, Fukuoka, 812-8581 Japan

\author{
Junichi YUKAWA \\ Entomological Laboratory, Faculty of Agriculture, Kyushu University, \\ Fukuoka, 812-8581 Japan
}

\begin{abstract}
A gall midge species forming leaf margin roll galls on Robinia pseudoacacia L. (Fabaceae) was newly found in Japan and South Korea. Based on morphological features, this gall midge was identified as Obolodiplosis robiniae (Haldemann), which is native to eastern North America. There was no sequential variation among five individuals from Japan and South Korea. Since $R$. pseudoacacia is an alien plant, this gall midge is likely to have entered Japan and South Korea from North America.

Key Words: gall midge, leaf margin roll gall, new distribution record, Robinia pseudoacacia, alien plant, Nearctic species.
\end{abstract}

\section{Introduction}

In July 2002, one of us, FK, found gall midge larvae forming leaf margin roll galls

* Contribution from the Entomological Laboratory, Faculty of Agriculture, Kyushu University, Fukuoka (Ser. 5, No. 96). 
on Robinia pseudoacacia L. (Fabaceae) in Fukuoka Prefecture, Japan. Almost simultaneously, a similar gall was also found in the suburbs of Seoul, South Korea by one of us, HL. The shape of these galls is very similar to each other, suggesting a possibility that the gall midges from both countries are identical. In this study, we identify the gall midge species from Japan and South Korea on the basis of morphology. We also compare sequences of partial mtDNA COI region between the Japanese and South Korean individuals to detect intra-specific variations at the DNA level, if they are identical.

Robinia pseudoacacia is a North American species and not native to eastern Asia (Satake et al., 1989), and no midge galls have been found so far on R. pseudoacacia in Japan and South Korea. As has been noted in Yukawa \& Uechi (1999), most of galling insects cannot expand their host range to alien species. Therefore, a question arises as to reasons why such a leaf margin roll gall was found on an alien plant. A possible explanation is discussed for this phenomenon based on information (Yukawa \& Masuda, 1996) including collection and distribution records of midge galls on fabaceous plants in Japan.

\section{Materials and Methods}

\section{Collection, preservation, and identification}

The larvae and pupae of the gall midge were collected by FK in July 2002 from $R$. pseudoacacia growing in the Kyushu University Forest, Sasaguri Town, Fukuoka Prefecture, Japan. Some of them were preserved in $75 \%$ ethanol for morphological study or in $99.5 \%$ acetone for DNA analysis. Remaining pupae and larvae were kept in a plastic bag to rear adults. The adults emerged from July 17 to 20 .

In South Korea, larvae of the gall midge were collected by HL on August 9, 2002 from Seodundong, Suwon, South Korea and kept in a plastic cage to rear adults. The adults emerged from August 11 to 13. Some of the adult specimens were sent to JY for identification. In addition to Suwon, this gall midge was observed in Anyang and Seoul from June to August 2002. Adult emergences were also observed on July 11-12 from the galls collected in Chungju and through May 27 to June 7 from the galls collected in Daejeon.

The generic position of these gall midges was determined using keys to genera of Cecidomyiidae (Gagné, 1981). The species identification was confirmed through the courtesy of Dr. R. J. Gagné by comparing the Japanese and South Korean specimens with those kept in the U.S. National Museum, Washington, D.C., USA.

The specimens that were used in this study are kept in the collection of Entomological Laboratory, Faculty of Agriculture, Kyushu University and that of Laboratory of Insect Systematics, College of Agriculture and Life Science, Seoul National University, South 
Korea. Some specimens are also kept in the U.S. National Museum, Washington, D.C., USA.

\section{DNA analysis}

For DNA analysis, three individuals of Japanese (collected on July 15, 2002) and two individuals of South Korean specimens (collected on August 9, 2002) were used. For every individual, total DNA was extracted from the whole body with the DNeasy tissue kit (Qiagen, Japan), following the manufacturer's instructions. A region of the cytochrome oxidase subunit I (COI) gene of mtDNA was amplified by polymerase chain reaction (PCR) (Saiki et al., 1988). This region has been effectively used for the analysis for intra- or inter-specific variations in various genera of Cecidomyiidae (Shirota et al., 1999; Yukawa et al., 2003; Uechi et al., submitted to Bull. Ent. Res.). The primers used for the amplification were as follows: forward; 5'-GGATCACCTGATATAGCATTCCC-3' (COIS) and reverse; 5'-CCCGGTAAAATTAAAATATAAACTTC-3'(COIA) (Funk et al., 1995). The amplified products were purified with QiAquick PCR purification kits (Qiagen, Japan) following the manufacturer's instructions. The purified products were sequenced by the dideoxynucleotide cycle sequencing procedure with the Dye-Terminator cycle sequencing procedure with the Dye-Terminator cycle sequencing kit (Perkin-Elmer, Warrington, UK) and TGRADIENT thermal cycler (Biometrica). Sequencing electrophoresis was done on an $11 \%$ Long Ranger ${ }^{\mathrm{TM}}$ gel with a LIC-4200S-2 automated DNA sequencer (Aloka Co. Ltd, USA). Both strands on the PCR products were sequenced.

The nucleotide sequence data reported in this paper will appear in the DNA Data Bank of Japan, European Molecular Biology Laboratory, and GenBank nucleotide sequence databases with the following accession numbers: AB106524- AB106528.

\section{Results and Discussion}

\section{Identification}

We confirmed that the gall midge species from Japan and South Korea have the following common characteristics: post vertical peak absent; palpus four-segmented; antenna with 12 flagellomeres; last flagellomere not tiny; tarsal claw simple, approximately as long as empodium on all legs; basal section of Rs strong; R5 joining C posterior to wing apex. Male genitalia (Fig. 1): cerci large, nearly divided; hypoproct modified into two orbicular lobes surrounding aedeagus; gonostylus setulose, long and narrow, longer than gonocoxite; mediobasal lobe not present.

Based on these characteristics, we concluded that the gall midges from Japan and South Korea are identical and belong to the genus Obolodiplosis Felt, 1908, which has 


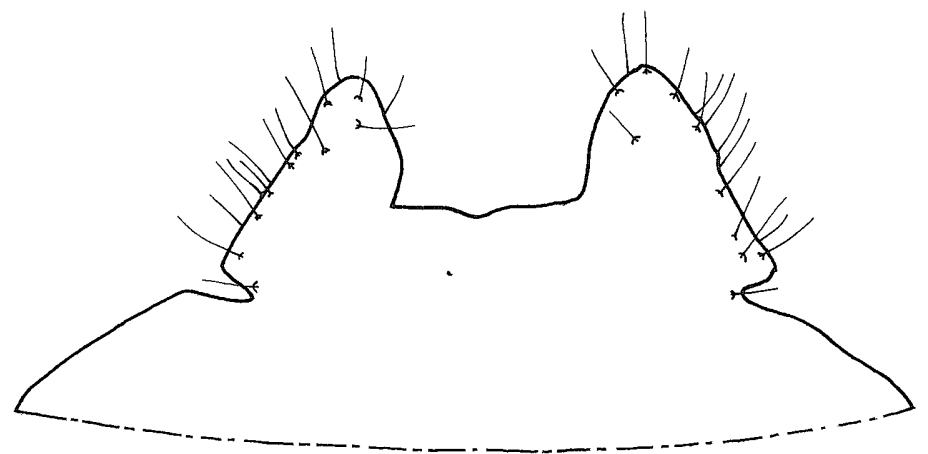

A

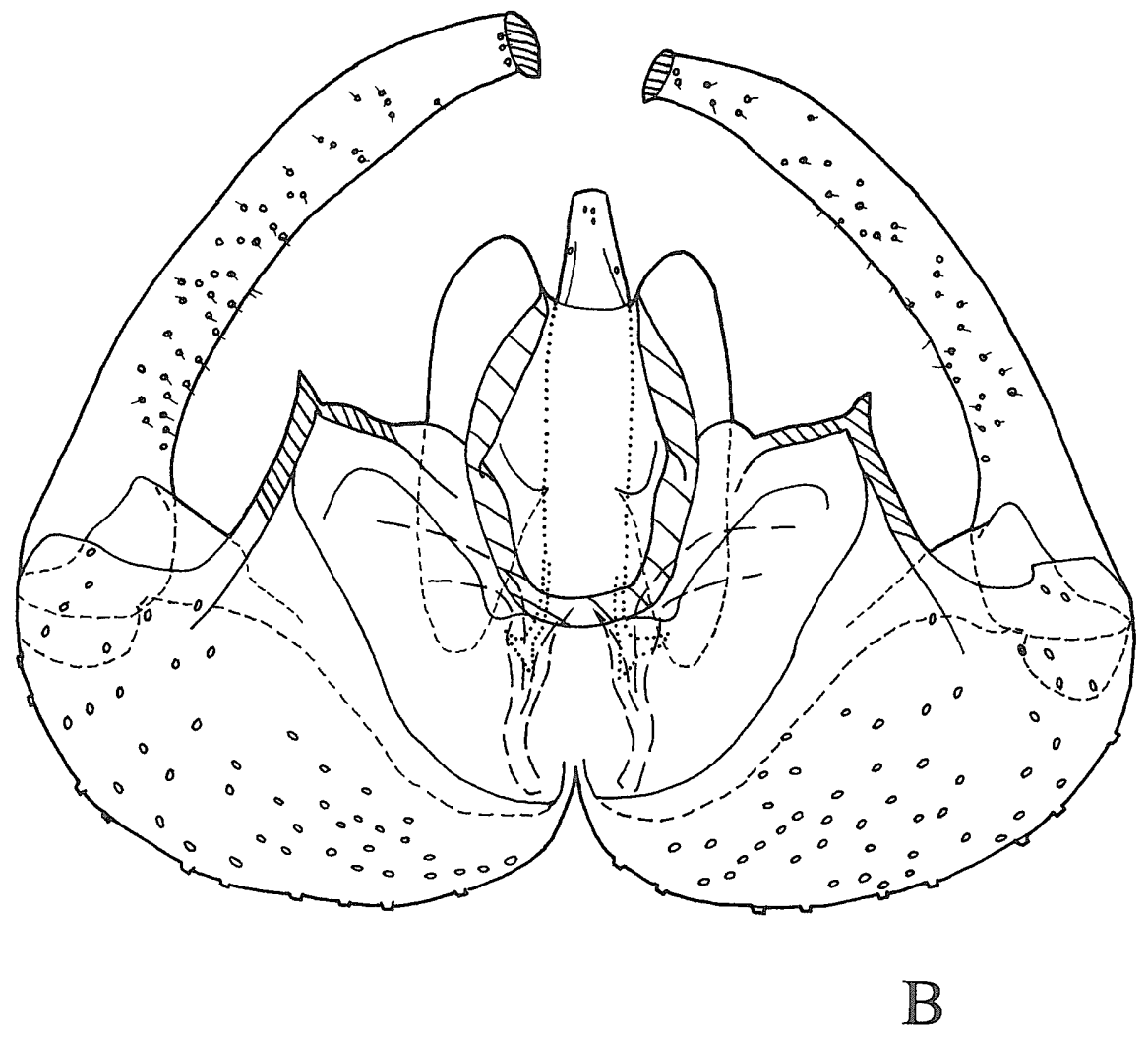

Fig. 1. Obolodiplosis robiniae (Haldemann). A: dorsal view of hypandrium and cerci; B: dorsal view of male genitalia, hypandrium and cerci are removed. 
only one species, Obolodiplosis robiniae (Haldemann, 1847), in the world. We identified the Japanese and Korean species as $O$. robiniae and Raymond J. Gagné (2002, personal communication) confirmed our identification.

\section{DNA analysis}

The amplified mtCOI gene fragment was $439 \mathrm{bp}$ long. This region corresponded to the bases 1752-2190 of the genome of Drosophila yakuba Burla (Diptera: Drosophilidae) (Clary \& Wolstenholme, 1985). There was no sequential variation among five individuals from Japan and South Korea (see the accession numbers indicated in the Materials and Methods). These results of DNA analysis supported the morphological confirmation that the Japanese and South Korean gall midges were identical.

\section{Accidental introduction}

In Japan, 16 sorts of insect galls are known to occur on fabaceous plants and 10 of them are midge galls (Yukawa \& Masuda, 1996). However, none of the midge galls are produced on $R$. pseudoacacia, although Aphis craccivora pseudoacaciae Takahashi (Aphididae) makes leaf roll galls on that plant (Yukawa \& Masuda, 1996). As shown in Gagné (1989), Obolodiplosis is a Nearctic genus and no gall midges of Obolodiplosis were previously recorded from eastern Asia. In addition, the only known host plant of O. robiniae is $R$. pseudoacacia, which is native to North America (Satake et al., 1989) and has been introduced first in 1877 to Japan from North America (Makino, 1940).

These evidences suggest that this gall midge is likely to have entered Japan from North America rather than expanded its host range to $R$. pseudoacacia from some other fabaceous plants native to eastern Asia.

The time of arrival is hardly determined, but there are a few evidences supporting its relatively recent arrival. There were no collection records of this gall midge until today in Japan, even though one of us, JY, and his colleagues have searched for galling arthropods on many occasions over a period of more than 30 years (Yukawa \& Masuda, 1996). In addition, this gall midge has never broken out in Japan and South Korea on $R$. pseudoacacia that is now widely planted in both countries, in spite of the fact that herbivores frequently increase their population density tremendously soon or some time after arrival at new habitats (e.g., Elton, 1958; Miyashita, 1977; Yukawa, 1984).

\section{Acknowledgements}

We would like to express our thanks to Dr. R. J. Gagné (Systematic Entomology Laboratory, PSI, Agricultural Research Service, USDA) for confirming our identification. Our thanks are also due to Dr. O. Tadauchi, Dr. S. Kamitani, Messrs. D. Yamaguchi, 
M. Tokuda, and S. Sato (Entomological Laboratory, Kyushu University) for their support and help.

\section{References}

Clary, D. O. \& D. R. Wolstenholme, 1985. The mitochondrial DNA molecule of Drosophila yakuba: nucleotide sequence, gene organization, and genetic code. $J$. Mol. Evol., 22: 252-271.

Elton, C. S., 1958. The Ecology of Invasions by Animals and Plants. Methuen \& Co., London, 181pp.

Felt, E. P., 1908. Appendix D. New Species of Cecidomyiidae II. N.Y. State Mus. Bull., 124: 286-422+pls. 33-44.

Funk, D. J., D. J. Futuyma, G. Orti \& A. Meyer, 1995. Mitochondrial DNA sequences and multiple data sets: a phylogenetic study of phytophagous beetles (Chrysomelidae: Opharaella). Mol. Biol. Evol., 12: 627-640.

Gagné, R. J., 1981. Cecidomyiidae. pp. 257-292. In McAlpine, J. F., B. V. Peterson, G. E. Shewell, H. J. Teskey, J. R. Vockeroth \& D. M. Wood (eds.), Manual of Nearctic Diptera Vol.1. Research Branch Agriculture, Canada.

Gagné, R. J., 1989. The Plant-Feeding Gall Midges of North America. Cornell University Press, Ithaca and London, 356pp.

Haldemann, S. S., 1847. Description of several new and interesting animals. Am. J. Agr. Sci., 6: 191-194.

Makino, T., 1940. Illustrated Flora of Nippon. Hokuryukwan, Tokyo, 1070pp. (In Japanese.)

Miyashita, K., 1977. Ecology of Naturalized Animals. Kôdansha, Tokyo, 213pp. (In Japanese.)

Saiki, R. K., D. H. Gelfand, S. Stoffel, R. Higuchi, G. T. Horn, K. B. Mullis \& H. A. Erlich, 1988. Primer-directed enzymatic amplification of DNA with a thermostable DNA polymerase. Science, 129: 487-491.

Satake, Y., H. Hara, S. Watari \& T. Tominari (eds.), 1989. Wild Flowers of Japan Woody Plants I. Heibonsha, Tokyo, 321+304 pls. (In Japanese.)

Shirota, Y., K. Iituka, J. Asano, J. Abe \& J. Yukawa, 1999. Intraspecific variations of mitochondrial cytochrome oxidase I sequence in an aphidophagous species, Aphidoletes aphidimyza (Diptera: Cecidomyiidae). Entomol. Sci., 2: 209-215.

Yukawa, J., 1984. Fruit flies of the genus Dacus (Diptera: Tephritidae) on the Krakatau Islands in Indonesia, with special reference to an outbreak of Dacus albistrigatus De Meijere. Jpn. J. Ecol., 34: 281-288.

Yukawa, J. \& H. Masuda, 1996. Insect and Mite Galls of Japan in Colors. Zenkoku 
Nôson Kyôiku Kyôkai, Tokyo, 826pp. (In Japanese with English explanations for color plates.)

Yukawa, J. \& N. Uechi, 1999. Can gallers expand the host range to alien plants within a short period of time? Esakia, (39): 1-7.

Yukawa, J., N. Uechi, M. Horikiri \& M. Tuda, 2003. Description of the soybean pod gall midge, Asphondylia yushimai sp. n. (Diptera: Cecidomyiidae), a major pest of soybean and findings of host alternation. Bull. Entomol. Res., 93: 73-86. 


$$
\text { . }
$$

